International Journal of Advanced Biological and Biomedical Research Available online at http:www.ijabbr.com

Volume 8, Issue 3 (2020) pp. 290-301

DOI: 10.33945/SAMI/IJABBR.2020.3.7

Original Article

\title{
Integrated Weed Control in Corn (Zea mays L.) Through Combinations of Seed Priming and Reduced Dosages of Herbicides
}

\author{
Marjan Diyanat*, Fereidoon Ghasemkhan-Ghajar \\ Department of Agriculturale Sciences and Food Industries, Science and Research Branch, \\ Islamic Azad University, Tehran, Iran \\ *Corresponding Author E-mail: Md dyanat@yahoo.com, m.diyanat@srbiau.ac.ir
}

Received: 12 October 2019, Revised: 22 December 2020, Accepted: 28 January 2020

\begin{abstract}
Field experiments were conducted during 2017 and 2018 to evaluate the efficacy of herbicides Nicosulfuron and EPTC alone or in combination with seed priming on weed control and corn yield. Nicosulfuron (80 g/a.i./ $/ \mathrm{ha}^{-1}$ ) was applied at four to six-leaf stage of corn as postemergence and EPTC (4920 g/a.i./ $/ \mathrm{ha}^{-1}$ ) applied as pre-plant incorporation (PPI). Among the herbicide treatments, the lowest total weed biomass was observed in plots treated with prime + EPTC PPI at $1 / 2$ recommended dose followed by one hand weeding and Nicosulfuron applied at label recommended dose or 33\% reduced dose integrated with seed priming, while the least performance was observed in plots treated with EPTC alone. Weed biomass reduction by seed priming alone was 32\% (average of two years) compared with the control one. The highest grain and biological yield were observed in weed free plots and hand hoeing three times, followed by prime + EPTC, one hand-hoeing and Nicosulfuron at recommended rate and at $33 \%$ reduced dose integrated with seed priming. The present study demonstrated that seed priming can improve the weed competitiveness of corn.
\end{abstract}

Key words: Density, Hand weeding, Weed biomass, Yield

\section{Introduction}

Corn (Zea mays L.) is one of the most widely planted crops in the world. In 2012, the total area under corn cultivation in Iran was 415,000 ha with an average yield of 5.8 ton ha ${ }^{-1}$ (FAOSTAT, 2012).

Effective weed control is essential to ensure high yields and good quality. Effective weed control in corn is a major concern because weeds can reduce yield up to 86\% (Bijanzadeh and Ghadiri, 2006). Weeds decrease corn production through competition for water, soil nutrients, light and space. It has been shown that corn yields can be severely reduced under weedy conditions (Chikoye et al., 2004). A lot of weed species contains monocot and dicot exists in corn field. Weed control in corn fields in Iran is dependent mainly on chemical methods. A wide range of herbicides with different mechanisms of action have been registered in corn including atrazine plus Allachlor, EPTC and 2,4-D plus MCPA (Mousavi, 2001; Hadizadeh et al., 2006), 
Nicosulfuron, Foramsulfuron, Rimsulfuron and Nicosulfuron+Rimsulfuron (Baghestani et al., 2007). Nicosulfuron, Foramsulfuron, Rimsulfuron belonging to sulfonylurea herbicides inhibit the first enzyme in the biosynthesis of branched-chain amino acids such as valine, leucine and isoleucine in chloroplasts (Rao, 2000). These herbicides control a lot of grass and some broadleaf weeds in corn, but they control grasses and sedges better than broadleaf weeds.

Post application of Nicosulfuron and pre-plant incorporated application of EPTC have a good efficacy on weed control. Although the use of herbicides to manage weed and achieve maximum yield is inevitable, it should be noted that high consumption of herbicides can lead to adverse environmental effects and the development of weed resistance (Mehdizadeh and Gholami Abadan, 2018). Most producers use herbicides at recommended rates and in most cases, they spray herbicides at higher rates. There is little published information regarding the minimum effective dose of herbicides to be used in the field (Zhang et al., 2013). The application of the reduced dose of herbicides can provide effective weed control in crops and mitigate the side effect of the herbicide on environment (Kudsk and Streibig, 2003). It is better to use a combination of cultural, mechanical, and chemical practices for more and better weed management. Considering high input of herbicides results in environmental pollution, the development of weed resistance and production costs, the application of the optimal doses of herbicides while reducing weed density at an acceptable level and protecting the crop from herbicide injury is essential (Nurse et al., 2007). The application of the reduced doses of herbicide not only can control weeds satisfactorily but also minimize the amounts of herbicide residues in the soils. The usage of herbicides at reduced doses can reduce the possible potential for carryover injury to current and succeeding susceptible crops, and mitigate threat to the environment (Blackshaw et al., 2006). On the other hand, owing to the persistent nature of sulfonylurea herbicide, their residues may be present at phytotoxic levels for subsequent vegetation (Paul et al., 2009). However, it was specified that low doses of herbicides can lead to speed up the evolution of herbicide resistance (Manalil et al., 2011; Norsworthy et al., 2012).

Hydropriming (soaking seed in water) can be an important option in IWM (integrated weed management). Hydropriming is a simple, low-cost approach which can improve crop competitiveness against weeds through increased germination rate, higher germination uniformity, and faster emergence of seedlings (Kaya et al., 2006; Farooq et al., 2007). The positive effects of seed priming on the competitive ability of rice against weeds have been demonstrated in previous works (Harris et al., 2002; Clark et al., 2001).

Combining reduced doses of herbicides with other management practices such as priming can help to weed management in corn fields. To the best of our knowledge, little or no research has been performed so far on the efficacy of seed priming as a sustainable option for weed management. Therefore, the present study was aimed to evaluate the efficacies of integration of seed priming and reduced dosages of herbicides in comparison with their application alone at the recommended rate for weed control in corn.

\section{Experimental}

\section{Field studies}

The aim of the present study was to evaluate the efficacies of integration of seed priming and reduced dosages of Nicosulfuron and EPTC for weed control in corn. So two-year (2017 and 2018) field experiments were conducted at Pakdasht, Tehran, Iran ( $51^{\circ} 44^{\prime} \mathrm{N} 33^{\circ} 28^{\prime} \mathrm{E}$, altitude $1180 \mathrm{~m}$ with semi-arid climate and a yearly average precipitation of $180 \mathrm{~mm}$ ) to evaluate the 
efficacy of weed control treatments on corn yield and associated weeds. The soil type was a clay-loam with $0.8 \%$ organic matter in 2017 and $0.94 \%$ in 2018 . The soil characteristics of the experimental site are presented in Table 1 . The field at the test site had lain fallow in preceding year of study. To prepare the seedbed, deep plowing $(20-25 \mathrm{~cm})$ was carried out with a moldboard plough each year in autumn followed by disking in the spring. The soil fertility was improved by applying diammonium phosphate (18-46-0 N-P-K) and urea the rate of 250 and $150 \mathrm{~kg} / \mathrm{ha}^{-1}$, respectively, each year in spring before planting. Moreover, $200 \mathrm{~kg} / \mathrm{ha}^{-1} \mathrm{~N}$ (as urea) was added at the 6-8 leaf growing stage of corn along with irrigation. Plots were $5 \mathrm{~m}$ long by $3 \mathrm{~m}$ wide constituting 4 rows of $75 \mathrm{~cm}$ apart. The corn hybrid "Singles Cross 704" (Corn hybrid "Single Cross 704" is a late maturing cultivar with broad leaf blade which can grow up to 3 meters) was sown at a density of 6 plant $\mathrm{m}^{-2}$ by hand on 12 May 2017 and 22 May 2018.

Table 1. Physical and chemical properties of the soil of the experimental site (depth of $0-30 \mathrm{~cm}$ )

\begin{tabular}{ccc}
\hline Parameters & \multicolumn{3}{c}{ Value } \\
\cline { 2 - 3 } & $\mathbf{2 0 1 7}$ & $\mathbf{2 0 1 8}$ \\
\hline Clay (\%) & 32 & 35 \\
Silt (\%) & 40 & 30 \\
Sand (\%) & 28 & 35 \\
Texture & Clay loam & Clay loam \\
Organic C (\%) & 0.8 & 0.94 \\
pH & 8.1 & 8.1 \\
EC (ds/m) & 1.98 & 1.65 \\
Available N (\%) & 0.07 & 0.08 \\
Available P2O5 (ppm) & 13.5 & 10.0 \\
Available K (ppm) & 195 & 224 \\
\hline
\end{tabular}

Abbreviations: CEC, cation exchange capacity (meq/100 g); EC, electrical conductivity (d $s / m$ )

\section{Experimental design and treatments}

Post-emergence application of Nicosulfuron (80 g a.i./ $\mathrm{ha}^{-1}$, Cruz ${ }^{\mathrm{TM}}$, SC 4\%, Bazargankala Company, Tehran, Iran) and pre-plant incorporation (PPI) application of EPTC (800 g/L, EPTC, Eradican $^{\mathrm{TM}}$, Golsam, Tehran, Iran) were used in the experiments.

Treatments consisted of Nicosulfuron at recommended dose (R), Nicosulfuron $2 / 3 \mathrm{R}+$ hydropriming (corn seeds were soaked in distilled water for $24 \mathrm{~h}$ in the lab with room temperature and then seeds were redried to original weight by air under shade), Nicosulfuron 1/2 R+hydropriming, EPTC R, EPTC 2/3 R+hydroprime, EPTC 1/2 R+hydropriming, hydropriming + EPTC 1/2R+one hand weeding, hydropriming, hydropriming + one hand hoeing. Treatments comprising of nonweeded check (weeds were allowed to grow), one hand weeding at the time of POST herbicide application, hand weedings two times at 3 and $6 \mathrm{wk}$ after sowing (WAS) of corn, hand weedings three times at 2, 4, and 6 WAS of corn, and weed-free plots (plots were kept free of weeds until harvest) were also included each year for comparison. The recommended doses of Nicosulfuron and EPTC were 80 and 4920 g/a.i./ha ${ }^{-1}$, respectively. EPTC was applied before corn planting while POST application of Nicosulfuron was made at the four-to six-leaf stage of corn on 10 June 2017 and 25 June 2018 (were applied at the four-leaf stage of weeds). No adjuvant was used with POST herbicides.

Herbicide treatments were applied with an electric knapsack sprayer (MATABI) (Goizeper S. Cooperative Company, Guipuzcoa, Spain) fitted with 8002 VS flat fan nozzles, calibrated to deliver $300 \mathrm{~L} / \mathrm{ha}^{-1}$ of spray solution at a pressure of $2.5 \mathrm{KPa}$. Experimental design was a randomized block with three replicates. 


\section{Data collection and analysis}

In primed and non-primes treatments, the seedlings were counted daily until complete emergence. The emergence of seedlings was completed within 15 days of sowing.

Germination percentage and emergence speed (ES) were calculated by the following formula:

Germination \%= Number of germinated seeds/number of seed sown* 100

Speed of mergence was calculated using the following formula (AOSA) (1983):

$$
\mathrm{ES}=\frac{N_{e s}}{D_{\text {firstcount }}}+\ldots \ldots .+\frac{N_{e s}}{D_{\text {finalcount }}}
$$

where $\mathrm{N}_{\mathrm{es}}$ is the number of emerged seeds and $\mathrm{D}$ is days.

After 8 WAS , the weeds in all trial plots were counted in the area of $3.75 \mathrm{~m}^{2}$ and the percent weed density and biomass reduction of each weed species were measured. All weeds were harvested at ground level, separated by species, counted and oven dried at $75 \mathrm{C}$ for $72 \mathrm{~h}$. Then, percent weed density and biomass reduction was measured by dividing weed density/biomass of a specific treatment by weed density/biomass in the weedy check multiplied by 100 (Zand et al., 2007). Corn was harvested at physiological maturity (8 October 2017 and 15 October 2018) and corn yield and yield components were determined by hand-harvesting cobs from 2 central rows for each plot.

All data were subjected to analysis of variance (ANOVA) using SAS statistical software (SAS 2003), and treatment means were separated using LSD at $\mathrm{P}<0.05$.

\section{Results and discussion}

\section{Seed germination}

Hydro-priming increased germination percentage and speed of emergence. Germination percentage and speed of emergence increased about $8 \%$ and 2 by hydro-priming (Table 2). Priming is found to be an important strategy to improving seed germination parameters. This strategy provides physiological and biochemical preparation for seed germination before planting and encountering environmental ecological conditions (Ahmadi et al., 2007). It has demonstrated that priming improved seed germination behavior and its related indices including the germination mean period, seed viability, germination rate and primary establishment of crop (Hussain et al., 2006).

Table 2. Effect of maize seeds hydro-priming on germination percentage and speed of emergence

\begin{tabular}{ccc}
\hline & \multicolumn{2}{c}{ Traits } \\
\cline { 2 - 3 } Treatment & Germination (\%) & $\begin{array}{c}\text { Speed of emergence } \\
\text { (number per day) }\end{array}$ \\
\hline Primed & 83.6 & 11.8 \\
Unprimed & 76.2 & 9.7 \\
LSD $(0.05)$ & 4.2 & 1.2 \\
\hline
\end{tabular}

The weed community was composed of 10 species in both years. Common purslane (Portulaca oleraceae L.), johnsongrass (Sorghum halepense L. Pers.) and redroot pigweed (Amaranthus retroflexus L.), jimsonweed (Datura stramonium L.) and prostrate pigweed (Amaranthus blitoides S. Wats.) were the predominant weed species in 2017; Weed populations were composed of predominantly of common purslane (Portulaca oleraceae L.), johnson grass 
(Sorghum halepense L. Pers.) and redroot pigweed (Amaranthus retroflexus L.), common lambsquarters (Chenopodium album L. ) and common cocklebur (Xanthium strumarium L.) in 2018 (Table 3).

Table 3. Mean weed density, by species, in the nontreated check treatment at Pakdasht in 2017 and 2018

\begin{tabular}{ccc}
\hline Weeds & \multicolumn{2}{c}{ Weed density plants/ $\mathbf{~ m}^{\mathbf{2}}$} \\
\cline { 2 - 3 } & $\mathbf{2 0 1 7}$ & $\mathbf{2 0 1 8}$ \\
\hline Portulaca oleraceae & 10.6 & 15.0 \\
Sorghum halepense & 8.3 & 14 \\
Amaranthus retroflexus & 7.3 & 12.6 \\
Chenopodium album & - & 3.0 \\
Datura stramonium & 9.6 & - \\
Xanthium strumarium & - & 5.6 \\
Amaranthus blitoides & 1.3 & - \\
\hline
\end{tabular}

" -" Indicates the absence of relevant weed in that year

\section{Weed control}

The weed control treatment for johnsongrass and common purslane were not consistent between the years $(\mathrm{P}<0.001)$. Thus, data from density and biomass reductions of johnsongrass and common purslane were analyzed separately for both years (Table 3). In 2017 and 2018, only Nicosulfuron at the recommended dose, prime+EPTC+OHW and hand weeding 3 times treatments provided $>90 \%$ johnsongrass control (Table 4 ). In both years, the reduction of johnsongrass density and biomass was good in treatments Nicosulfuron when they were applied at their label recommended doses or in combination with priming. EPTC did not provide good control of johnsongrass whether it was applied at their label recommended doses or in combination with priming (Tables 4 and 5).

Table 4. Percent density reduction of weeds at crop maturity in the 2017 and 2018 growing seasons at Pakdasht, Iran

\begin{tabular}{|c|c|c|c|c|c|c|c|c|c|c|}
\hline \multirow[t]{3}{*}{ Treatment } & \multirow[t]{3}{*}{ dose } & \multicolumn{9}{|c|}{ Weed species } \\
\hline & & \multicolumn{2}{|c|}{ SORHA } & \multicolumn{2}{|c|}{$\overline{\text { POROL }}$} & \multirow[t]{2}{*}{ AMAREc } & \multirow[t]{2}{*}{ CHEALd } & \multirow[t]{2}{*}{ XANSTR $^{d}$} & \multirow{2}{*}{$\frac{\text { DATST }^{d}}{2017}$} & \multirow{2}{*}{$\frac{\overline{\text { AMABL }^{\mathrm{d}}}}{2018}$} \\
\hline & & 2017 & 2018 & 2017 & 2018 & & & & & \\
\hline $\mathrm{N}$ & $\mathrm{R}^{\mathrm{b}}$ & 90.1 & 90.1 & 87.7 & 80.0 & 75.6 & 58.3 & 80.8 & 82.3 & 88.9 \\
\hline $\mathrm{P}+\mathrm{N}$ & $2 / 3 \mathrm{R}$ & 83.1 & 80.3 & 88.6 & 87.7 & 70.1 & 67.1 & 76.6 & 82.3 & 88.9 \\
\hline $\mathrm{P}+\mathrm{N}$ & $1 / 2 \mathrm{R}$ & 62.2 & 57.1 & 77.9 & 67.7 & 59.7 & 46.1 & 46.7 & 54.8 & 55.6 \\
\hline EPTC & $\mathrm{R}$ & 70.7 & 75.5 & 75.4 & 60.0 & 72.9 & 50.0 & 57.5 & 65.3 & 77.8 \\
\hline P+EPTC & $2 / 3 \mathrm{R}$ & 78.6 & 75.5 & 79.3 & 67.7 & 62.6 & 40.3 & 57.5 & 68.4 & 66.7 \\
\hline P+EPTC & $1 / 2 \mathrm{R}$ & 62.8 & 68.0 & 71.3 & 46.4 & 50.7 & 36.1 & 46.7 & 48.5 & 44.4 \\
\hline $\mathrm{P}+\mathrm{EPTC}+\mathrm{OHW}$ & $1 / 2 \mathrm{R}$ & 92.5 & 90.1 & 92.2 & 87.7 & 75.6 & 77.8 & 80.8 & 86.4 & 88.9 \\
\hline $\mathrm{P}$ & - & 44.6 & 33.3 & 33.1 & 30.7 & 30.6 & 30.1 & 30.0 & 32.5 & 38.9 \\
\hline $\mathrm{P}+\mathrm{OHW}$ & - & 56.4 & 51.1 & 55.0 & 47.7 & 42.2 & 41.3 & 61.7 & 54.8 & 50.0 \\
\hline HW 3 times & - & 100.0 & 100.0 & 100.0 & 98.4 & 100.0 & 94.4 & 95.8 & 97.0 & 100.0 \\
\hline HW 2 times & - & 83.1 & 78.5 & 75.1 & 70.5 & 70.1 & 72.2 & 72.5 & 76.4 & 100.0 \\
\hline OHW & - & 28.3 & 35.9 & 31.3 & 26.2 & 27.2 & 27.8 & 30.0 & 35.2 & 38.9 \\
\hline Weedy & - & - & - & - & - & - & - & - & - & - \\
\hline LSD $(0.05$ & & 9 & 6 & 17 & 13 & 22 & 25 & 18 & 12 & 32 \\
\hline
\end{tabular}

a Abbreviations:N, Nicosulfuron; P, seed priming; OHW, one hand weeding; HW, hand weeding; SORHA, Sorghum halepense; POROL, Portulaca oleraceae; AMARE, Amaranthus retroflexus; CHEAL, Chenopodium album; XANSTR, Xanthium strumarium; DATST, Datura stramonium; AMABL, Amaranthus blitoides b R means the producer recommended dose: 80 g/a.i./ha ${ }^{-1}$ for Nicosulfuron and 4920 g/a.i./ha-1 for EPTC 
c Data from 2017 and 2018 were pooled

d Datura stramonium and Amaranthus blitoides were only present in 2017; Chenopodium album and Xanthium strumarium were only present in 2018

Among weed species, the highest density was related to common purslane. In 2017 and 2018, the reduction of common purslane density and biomass ranged from $26 \%$ to $100 \%$ over the treatments (Tables 4 and 5). Regardless of three-time hand weeding treatment which was significantly different from all other treatments, as observed in Tables 4 and 5, the application of Nicosulfuron at the highest dose or combination of its 33\% reduced dose with priming and prime+EPTC+OHW treatment provided the highest reduction in common purslane density and biomass.

Table 5. Percent biomass reduction of weeds and total weed density at crop maturity in the 2017 and 2018 growing seasons at Pakdasht, Iran ${ }^{a}$

\begin{tabular}{|c|c|c|c|c|c|c|c|c|c|c|}
\hline \multirow[t]{3}{*}{ Treatment } & \multirow[t]{3}{*}{ dose } & \multicolumn{9}{|c|}{ Weed species } \\
\hline & & \multicolumn{2}{|c|}{ SORHA } & \multicolumn{2}{|c|}{ POROL } & \multirow[t]{2}{*}{ AMAREc } & \multirow[t]{2}{*}{ CHEALd $^{d}$} & \multirow[t]{2}{*}{ XANSTR $^{\mathbf{d}}$} & \multirow{2}{*}{$\frac{\text { DATSTd }^{d}}{2017}$} & \multirow{2}{*}{$\frac{\text { AMABL }^{\mathrm{d}}}{2018}$} \\
\hline & & 2017 & 2018 & 2017 & 2018 & & & & & \\
\hline $\mathrm{N}$ & $\mathrm{R}^{\mathrm{b}}$ & 93.9 & 83.3 & 87.1 & 80.0 & 76.4 & 79.2 & 80.4 & 87.1 & 90.1 \\
\hline $\mathrm{P}+\mathrm{N}$ & $2 / 3 \mathrm{R}$ & 83.1 & 75.5 & 84.1 & 74.7 & 78.3 & 77.7 & 75.0 & 83.6 & 88.3 \\
\hline $\mathrm{P}+\mathrm{N}$ & $1 / 2 \mathrm{R}$ & 68.1 & 62.6 & 64.7 & 57.3 & 57.5 & 56.5 & 55.2 & 57.4 & 48.3 \\
\hline EPTC & $\mathrm{R}$ & 73.7 & 75.7 & 75.1 & 65.9 & 68.9 & 68.6 & 67.5 & 75.2 & 73.0 \\
\hline P+EPTC & $2 / 3 \mathrm{R}$ & 75.4 & 79.5 & 73.1 & 69.2 & 70.6 & 66.7 & 70.5 & 70.4 & 66.3 \\
\hline P+EPTC & $1 / 2 \mathrm{R}$ & 60.4 & 52.9 & 58.3 & 42.1 & 53.7 & 40.3 & 40.7 & 50.2 & 49.0 \\
\hline $\mathrm{P}+\mathrm{EPTC}+\mathrm{OHW}$ & $1 / 2 \mathrm{R}$ & 91.7 & 93.2 & 89.4 & 84.9 & 85.6 & 77.7 & 84.2 & 80.4 & 88.4 \\
\hline $\mathrm{P}$ & - & 28.8 & 36.5 & 31.3 & 28.1 & 33.4 & 26.6 & 33.3 & 27.8 & 30.9 \\
\hline $\mathrm{P}+\mathrm{OHW}$ & - & 35.9 & 46.9 & 47.9 & 38.4 & 48.2 & 44.7 & 47.4 & 54.8 & 40.3 \\
\hline HW 3 times & - & 100.0 & 100.0 & 100.0 & 94.7 & 100.0 & 90.6 & 96.4 & 94.5 & 100.0 \\
\hline HW 2 times & - & 80.6 & 83.4 & 83.5 & 81.0 & 73.5 & 75.1 & 78.2 & 83.1 & 100.0 \\
\hline OHW & - & 27.8 & 31.5 & 33.3 & 27.6 & 36.3 & 30.7 & 27.6 & 25.7 & 26.2 \\
\hline Weedy & - & - & - & - & - & - & - & - & - & - \\
\hline LSD $(0.05$ & & 12 & 18 & 11 & 21 & 28 & 13 & 23 & 10 & 8 \\
\hline
\end{tabular}

a Abbreviations:N, Nicosulfuron; P, seed priming; OHW, one hand weeding; HW, hand weeding; SORHA, Sorghum halepense; POROL, Portulaca oleraceae; AMARE, Amaranthus retroflexus; CHEAL, Chenopodium album; XANSTR, Xanthium strumarium; DATST, Datura stramonium; AMABL, Amaranthus blitoides

b R means the producer recommended dose: 80 g/a.i./ $/ \mathrm{ha}^{-1}$ for Nicosulfuron and $4920 \mathrm{~g} / \mathrm{a}$.i. $/ \mathrm{ha}^{-1}$ for EPTC

c Data from 2017 and 2018 were pooled

d Datura stramonium and Amaranthus blitoides were only present in 2017; Chenopodium album and Xanthium strumarium were only present in 2018

None of the experimental treatments reduced common lambsquarters density or biomass satisfactorily, except for hand weeding 3 times. The reduction of common lambsquarters density and biomass was within the range of $36 \%$ to $77 \%$ over the herbicide treatments (Tables 4 and 5).

The application of Nicosulfuron at its label recommended dose and also prime+EPTC+OHW treatment provided a satisfactory control of common cocklebur. However, no significant differences were found between these treatments and the combination of Nicosulfuron 33\% reduced dose + priming treatment (Tables 4 and 5). The maximum reduction in jimsonweed density and biomass was found in plots that were hand weeded for 3 times, followed by prime + EPTC + OHW and Nicosulfuron. In 2017, hand weeding twice and three times could control provide excellent control of prostrate pigweed in corn. Among the herbicide treatments, Nicosulfuron provided the highest reduction in prostrate pigweed density and biomass when it 
was applied at its label recommended dose or its 33\% reduced dose integrated with seed priming. Treatment EPTC PPI integrated with priming and followed by one hand weeding gave also similar efficacy on prostrate pigweed (Tables 4 and 5).

The initial emergence and growth is very critical in competition output of crop and weed. (Kurokawa et al., 2015) studied the relationship between the relative photosynthetic photon flux density at the emergence time of Ipomoea coccinea seedlings and concluded that the I. coccinea seedlings that emerged at a relative photosynthetic photon flux densities (PPFDs) of less than 49\% were unable to grow normally and eventually died. (Murdock et al., 1986) also reported that a 4-week weed-free period in the $30 \mathrm{~cm}$ or $61 \mathrm{~cm}$ row-spacing treatment resulted in a zero dry weight of I. lacunosa, while the relative PPFDs were $80-90 \%$.

Total weed dry biomass in the weedy control plots averaged 220 and $187.5 \mathrm{~g} / \mathrm{m}^{-2}$ in 2017 and 2018, respectively, and was greater as compared to other weed control treatments. Hand weeding 3 times resulted in the lowest total weed biomass in both 2017 and 2018 (4 and $10 \mathrm{~g}$ $\mathrm{m}^{2}$, respectively). Among the herbicide treatments, the lowest total weed biomass was observed in plots treated with prime+EPTC PPI at $1 / 2 \mathrm{R}$ followed by hand weeding once and Nicosulfuron whether it was applied at its label recommended dose or its $33 \%$ reduced dose integrated with seed priming, while the poorest performance was observed in plots treated with EPTC.

Seed priming remarkably reduced weed biomass in both years. Weed biomass reduction by seed priming alone was 32\% (average of two years) compared with the control. No significant difference was found between one-time hand weeding and seed priming treatments. However, seed priming followed by one hand weeding resulted in 32\% (average of two years) reduction in weed biomass compared with control so that it was comparable with some herbicides treatments. Scientists increased germination percentage, germination rate and percentage of emergence in different plants by using priming technique. As a result of this sustainability, seedlings and their ability to compete with weeds increase and eventually increase plant yield. (Abbasdokht et al., 2012) reported that hydropriming in combination with hand-hoeing or Nicosulfuron herbicide provided better weed control and higher corn yield than application of Nicosulfuron alone. (Ullah et al., 2008) reported that pendimethalin PRE followed by hand weeding effectively reduced weeds density in the corn filed.

\section{Grain yield and yield components}

The interaction between the year weed control and treatments was not significant with most yield parameters except grain yield $(P=0.90)$. Corn yield attributes including plant height, number of rows per cob, number of kernels in rows, 1000- grain weight, biomass and grain yield were affected by the weed control treatments (Table 6).

In 2017 and 2018, weeds growing with corn reduced corn grain yields by $43 \%$ and $48 \%$ in the weedy check plots compared to the weed free control plots. Yield losses of 60 to $90 \%$ in corn due to weeds have been documented in previous studies (Dalley et al., 2006; Abouziena et al., 2007). All weed control treatments increased grain and biological yield as compared with the weedy control (Table 6). The highest grain and biological yield were observed in plots with hand hoeing three times and weed free. Also, prime+EPTC followed one hand-hoeing and Nicosulfuron whether it was applied at its label recommended dose or its 33\% reduced dose integrated with seed priming significantly increased corn yield and components as compared with the no weeded control. 
Table 6. Effects of treatments on total weed biomass corn yield and its components during the 2017 and 2018 growing season at Pakdasht, Iran ${ }^{a}$

\begin{tabular}{|c|c|c|c|c|c|c|c|c|c|c|}
\hline \multirow{2}{*}{ Treatment } & \multirow[b]{2}{*}{ dose } & \multicolumn{2}{|c|}{$\operatorname{TWB}\left(\mathrm{g} / \mathrm{m}^{-2}\right)$} & \multirow[t]{2}{*}{$\begin{array}{l}\text { Plant } \\
\text { heigh' } \\
\text { (cm) }\end{array}$} & \multirow[t]{2}{*}{$\begin{array}{l}\text { No. of } \\
\text { rows }\end{array}$} & \multirow{2}{*}{$\begin{array}{c}\text { No. of } \\
\text { kernels } \\
\text { In rows }\end{array}$} & \multirow{2}{*}{$\begin{array}{c}\text { 1,000- } \\
\text { grain } \\
\text { Weightc } \\
\text { (g) }\end{array}$} & \multirow{2}{*}{$\begin{array}{l}\text { Biomass } \\
\text { yieldc } \\
\text { (ton/ ha-1) }\end{array}$} & \multicolumn{2}{|c|}{$\begin{array}{c}\text { Grain yield } \\
\left(\mathrm{kg} / \mathrm{ha}^{-1}\right)\end{array}$} \\
\hline & & 2017 & 2018 & & & & & & 2017 & 2018 \\
\hline $\mathrm{N}$ & $\mathrm{R}^{\mathrm{b}}$ & 20.0 & 32.4 & 229.1 & 12.9 & 32.6 & 244.5 & 31.058 & 9.231 & 8.519 \\
\hline $\mathrm{P}+\mathrm{N}$ & $2 / 3 \mathrm{R}$ & 27.9 & 30.3 & 226.5 & 12.8 & 32.6 & 243.8 & 31.373 & 9.320 & 8.396 \\
\hline $\mathrm{P}+\mathrm{N}$ & $1 / 2 R$ & 85.2 & 75.1 & 208.4 & 12.1 & 28.7 & 239.4 & 28.573 & 7.328 & 7.492 \\
\hline EPTC & $\mathrm{R}$ & 60.3 & 50.0 & 219.6 & 12.3 & 30.5 & 240.4 & 27.600 & 8.243 & 7.679 \\
\hline P+EPTC & $2 / 3 \mathrm{R}$ & 98.0 & 75.5 & 222.3 & 12.3 & 30.3 & 240.3 & 28.500 & 8.300 & 7.766 \\
\hline P+EPTC & $1 / 2 R$ & 120.4 & 90.0 & 199.8 & 12.1 & 27.0 & 238.1 & 26.663 & 7.246 & 7.066 \\
\hline $\mathrm{P}+\mathrm{EPTC}+\mathrm{OHW}$ & $1 / 2 R$ & 22.5 & 25.6 & 227.4 & 12.9 & 32.6 & 244.6 & 31.100 & 9.236 & 8.438 \\
\hline $\mathrm{P}$ & - & 147.5 & 130.0 & 193.5 & 11.7 & 25.9 & 229.2 & 26.280 & 6.754 & 6.166 \\
\hline $\mathrm{P}+\mathrm{OHW}$ & - & 116.2 & 105.1 & 209.2 & 12.1 & 27.7 & 235.0 & 27.900 & 7.241 & 7.139 \\
\hline HW 3 times & - & 4.0 & 10.0 & 235.9 & 13.7 & 35.5 & 246.5 & 32.313 & 9.843 & 8.769 \\
\hline HW 2 times & - & 25.3 & 42.5 & 220.6 & 12.9 & 32.6 & 242.3 & 29.863 & 8.833 & 7.986 \\
\hline OHW & - & 142.5 & 137.9 & 194.0 & 11.7 & 26.1 & 228.3 & 26.093 & 6.690 & 6.126 \\
\hline Weedy & - & 220.0 & 187.5 & 171.7 & 10.7 & 23.3 & 213.8 & 22.995 & 5.656 & 4.850 \\
\hline Weed-free & - & - & - & 243.5 & 13.8 & 35.9 & 247.3 & 33.494 & 10.026 & 9.372 \\
\hline $\operatorname{LSD}(0.05)$ & & 33 & 26 & 11 & 0.45 & 1.6 & 4 & 1.048 & 4.74 & 3.46 \\
\hline
\end{tabular}

aAbbreviations: TWB, total weed biomass; N, Nicosulfuron; P, seed priming; OHW, one hand weeding; HW, hand weeding

b $\mathrm{R}$ means the producer recommended dose: $80 \mathrm{~g} / \mathrm{a}$.i./ha ${ }^{-1}$ for Nicosulfuron and $4920 \mathrm{~g} / \mathrm{a} . \mathrm{i} . / \mathrm{ha}^{-1}$ for EPTC

c Data from 2017 and 2018 were pooled

None of the herbicide treatments led to superior grain yields as compared to hand-weeding three times in both years. Corn grain yields under herbicide treatments were significantly higher than those of the weedy control whether they were applied at the recommended doses or at reduced doses (33\% to $50 \%$ ) in both years. Compared with the weedy control, the corn grain yield reduced 30 to $43 \%$ in 2017 and 21 to 39\% in 2018 over the herbicide treatments (Table 6). In both years, corn grain yields in herbicides treatments were not significantly different whether herbicides were applied at the recommended doses or at $33 \%$ reduced doses integrated with seed priming. Seed priming alone increased grain yield by $15 \%$ in 2017 and $21 \%$ in 2014 as compared with weedy control. Grain yield in plots with hand weeding once resulted in yields similar to the seed priming treatment (Table 6). Our findings are in agreement with the findings of (Jalali and Salehi, 2013), who found that seed priming can increase weed competitiveness of sugar beet but different from (Zhao et al., 
2007) findings who found no significant influence of seed priming on weed suppression in aerobic rice. (Ghiyasi et al., 2008) also reported that due to seed priming robust seedling establishment could help weed competitiveness of wheat.

\section{Conclusion}

The present study highlights that the use of appropriate herbicides or other weed control methods is needed to obtain the optimum yield in corn. The findings from this research indicated that it is possible to increase the weed-suppressive ability of corn by seed priming. Seed priming may improve grain yield of corn by reducing risk of poor stand establishment and increasing weed competitiveness. Among the herbicides, Nicosulfuron could effectively control weed species and resulted in higher corn grain yield. Our results also show that a 50\% reduced dose application of Nicosulfuron and EPTC integrated with seed priming did not provide sufficient weed control and thereby corn yield in both years. It is worth noting that $33 \%$ reduced dose application of herbicide in combination with seed priming could control weeds satisfactorily. Accordingly, it is suggested to integrate reduced doses of herbicide with mechanical and cultural controls. In conclusion, this study indicated that hydropriming can increase the weed suppressive ability of corn, and consequently, it may help increase the grain yield by reducing the risks of poor stand establishment and crop losses due to weeds.

\section{References}

Abasdokht, H, Makarian, H, Gholami, A, Rahimi, M. (2012). The study of integrated weed management (IWM), emphasizing the effect of seed priming on yield and yield components of corn (Zea mays L.). Iran. J. Weed Sci., 4:63-76.

Abouziena, HF, El-Karmany, MF, Singh, M, Sharma, SD. (2007). Effect of Nitrogen Rates and Weed Control Treatments on Corn Yield and Associated Weeds in Sandy Soils. Weed Technol., 21:1049-1053.

Ahmadi, A, Sio-Semardeh, A, Poustini, K, Esmailpour Jahromi, M. (2007). Influence of osmo and hydro priming on seed germination and seedling growth in wheat (Triticum aestivum L.) cultivars under different moisture and temperature conditions. Pakistan J. Biol. Sci., 10:4043-4049.

AOSA (1983). Seed Vigor Hand Testing Book, Contribution No. 32 to the Handbook on Seed Testing. Association of Official Seed Analysts, Springfield, IL, USA.

Baghestani, MA, Zand, E, Soufizadeh, S, Eskandari, A, Pour Azar, R, Veysi, M, Nassirzadeh, N. (2007). Efficacy evaluation of some dual purpose herbicides to control weeds in corn (Zea mays L.). Crop. Prot., 26:936-942.

Bijanzadeh, E, Hossein, G. (2006). Effect of separate and combined treatments of herbicides on weed control and corn (Zea mays L.) yield. Weed Technol., 20:40-645.

Blackshaw, RE, O’Donovan, JT, Harker, KN, Clayton, GW, Stougaard, RN. (2006). Reduced herbicide doses in field crops: a review. Weed Bio. Manag., 6:10-17. 
Chikoye, D, Schulz, S, Ekeleme, F. (2004). Evaluation of integrated weed management practices for corn in the northern Guinea savanna of Nigeria. Crop Prot., 23:895-900.

Clark, LJ, Whalley, WR, EllisJones, J, Den, K, Rowse, HR, Finch-Savage, WE, Gatsai, T, Jasi, L, Kaseke, NE, Murungu, FS, Riches, CR, Chiduza, C. (2001). On farm seed priming in corn: a physiological evaluation, pp. 268273. Seventh Eastern and Southern Africa Regional Corn Conference, 11-15 February.

Dalley, CD, Bernards, ML, Kells, JJ. (2006). Effect of weed removal timing and row spacing on soil moisture in corn (Zea mays L.). Weed Technol., 20:399-409.

Ellis, RA, Roberts, EH. (1981). The quantification of ageing and survival in orthodox seeds. Seed Sci. Technol., 9:373-409.

FAOSTAT (2012). Agriculture Data. http://www.faostat.fao.org.

Farooq, M, Basra, SMA, Ahmad, N (2007). Improving the performance of transplanted rice by seed priming. Plant Growth Regul., 51:129-137.

Ghiyasi, M, Abbasi, AM, Tajbakhsh, A, Sallehzade, R. (2008). Effect of osmopriming with polyethylene glycol 8000 (PEG8000) on germination and seedling growth of wheat (Triticum aestivum L.) seeds under salt stress. Res. J. Biol. Sci., 3:1249-1251.

Hadizadeh, MH, Alimoradi, L, Fereidoonpour, M. (2006). Evaluation of sulfonylurea herbicides in grain corn (Zea mays L.). In: Proceedings First Iranian Weed Science Congress. Tehr. Iran, pp. 519-523.

Harris, D, Tripathi, RS, Joshi, A. (2002). On-farm seed priming to improve crop establishment and yield in dry direct-seeded rice. In S Pandey, M Mortimer, L Wade, TP Tuong, K Lopes, and B Hardy (Eds.), Proceedings of the International Workshop on Direct Seeding in Asian Rice Systems: Strategic Research 297 Issues and Opportunities. 25-28 January 2000. Bangkok, Thailand.

Hussain, M, Farooq, M, Basra, SMA, Ahmad, N. (2006). Influence of seed priming techniques on the seedling establishment, yield and quality of hybrid sunflower. Int. J. Agric. Biol., 8:14-18.

Jalali, AH, Selehi, F. (2013) Sugar beet yield as affected by seed priming and weed control. Arch. Agron. Soil Sci., 59:281-288.

Karimmojeni, H, Rahimian Mashhadi, H, Shahbazi, S, Taab, AR, Alizadeh, HM. (2010). Competitive interaction between corn, Xanthium strumarium L. and Datura stramonium L. affecting some canopy characteristics. Aust. J. Crop. Sci., 4:684-691.

Kaya, MD, Okcub, G, Ataka, M, Cikilic, Y, Kolsaricia, O. (2006). Seed treatments to overcome salt and drought stress during germination in sunflower (Helianthus annuus L.). Eur. J. Agr., 24:291-295. 
Kudsk, P, Streibig, JC. (2003). Herbicides-a-two-edged sword. Weed Res., 43:90-102.

Manalil, S, Busi, R, Renton, M, Powles, SB. (2011). Rapid evolution of herbicide resistance by low herbicide dosages. Weed Sci., 59:210-217.

Kurokawa, S, Hajika, M, Shibuya, T. (2015). Canopy height-to-row spacing ratio as a simple and practical onsite index to determine the time for terminating Ipomoea coccinea control in the Japanese soybean-growing systems. Weed Bio. Manag., 15:113121.

Mehdizadeh, M, Gholami-Abadan, F. (2018). Negative effects of residual herbicides on sensitive crops: impact of rimsulfuron herbicide soil residue on sugar beet. J. Res. Weed Sci., 1:1-6.

Mousavi, MR. (2001). Integrated Weed Management: Principles and Methods, first ed. Meiad Press.

Murdock, EC, Banks, PA, Toler, JE. (1986). Shade development effects on pitted morning glory (Ipomoea lacunosa) interference with soybeans (Glycine max). Weed Sci., 34:711717.

Norsworthy, JK, Ward, SM, Shaw, DR, Llewellyn, RS, Nichols, RL, Webster, TM, Bradley, KW, Frisvold, G, Powles, SB, Burgos, NR, Witt, WW, Barrett, M. (2012). Reducing the risks of herbicide resistance: best management practices and recommendations. Weed Sci., 60:31-62.

Nurse, RE, Hamill, AS, Swanton, CJ, Tardif, FJ, Sikkema, PH. (2007). Weed control and yield response to foramsulfuron in corn. Weed Technol., 21:453-458.

Paul, R, Sharma, R, Kulshrestha, G, Singh, SHB. (2009). Analysis of metsulfuron-methyl residues in wheat field soil: a comparison of HPLC and bioassay techniques. Pest Manag. Sci., 65:963-968.

Rao, VS. (2000). Principles of Weed Science. New Hampshire: Science Publishers, Inc.

Ullah W, Khan MA, Sadiq M. (2008). Evaluation of integrated weed management practices for corn. Pakistan J. Weed Sci. Res., 14:19-32.

Zhang, J, Zheng, L, Jäck, O, Yan, D, Zhang, Z, Gerhards, R, Ni, H. (2013). Efficacy of four post-emergence herbicides applied at reduced doses on weeds in summer corn (Zea mays L) fields in North China Plain. Crop Prot., 52:26-32.

Zand, E, Baghestani, MA, Soufizadeh, S, Eskandari, A, PourAzar, R, Veysi, M, Mousavi, K, Barjasteh, A. (2007). Evaluation of some newly registered herbicides for weed control in wheat (Triticum aestivum L.) in Iran. Crop Prot., 26:1349-1358. 
Zhao, DL, Bastiaans, L, Atlin, GN, Spiertz, JHJ. (2007). Interaction of genotype $\times$ management on vegetative growth and weed suppression of aerobic rice. Field Crop. Res., 100:327-340.

How to cite this article: Marjan Diyanat, Fereidoon Ghasemkhan-Ghajar, Integrated Weed Control in Corn (Zea mays L) Through Combinations of Seed Priming and Reduced Dosages of Herbicides. International Journal of Advanced Biological and Biomedical Research, 2020, 8(3), 290-301. Link: http://www.ijabbr.com/article 38088.html 